\title{
Revisiting African Agriculture: Institutional Change and Productivity Growth
}

\section{Citation}

Bates, Robert H., and Steven A. Block. 2013. "Revisiting African Agriculture: Institutional Change and Productivity Growth." Journal of Politics 75 (2) (April): 372-384. doi:10.1017/ s0022381613000078. http://dx.doi.org/10.1017/S0022381613000078.

\section{Published Version}

doi:10.1017/s0022381613000078

\section{Permanent link}

http://nrs.harvard.edu/urn-3:HUL.InstRepos:12040041

\section{Terms of Use}

This article was downloaded from Harvard University's DASH repository, and is made available under the terms and conditions applicable to Open Access Policy Articles, as set forth at http:// nrs.harvard.edu/urn-3:HUL.InstRepos:dash.current.terms-of-use\#OAP

\section{Share Your Story}

The Harvard community has made this article openly available.

Please share how this access benefits you. Submit a story.

Accessibility 


\title{
Revisiting African Agriculture: Institutional Change and Productivity Growth ${ }^{1}$
}

\author{
Robert H. Bates
}

Harvard University

Steven A. Block

Tufts University

\footnotetext{
${ }^{1}$ We wish to thank the Weatherhead Center, Harvard University, and the National Bureau of Economic Research, Cambridge MA, for support for this (and related) research and to acknowledge the assistance of Kaiyang Huang and Brett Carter. We thank the editors for recruiting an able set of reviewers and the reviewers themselves for their criticisms and advice. We have posted the definitions and of our variables, the sources from which they were taken and descriptive statistics in an online Appendix, which appears at EDITOR TO PROVIDE ADDRESS, along with material excised from the article for want of space. The replication data will be posted at http://scholar.harvard.edu/rbates and http://fletcher.tufts.edu/Fletcher_Directory/Directory/Faculty\%20Profile?personkey=F85945AF-9382-4B28-AAA1-
} 2F992574D74B 


\section{Abstract}

Africa is largely agrarian and the performance of agriculture shapes the performance of its economies. It has long been argued that economic development in Africa is strongly conditioned by politics. Recent changes in Africa's political systems enables us to test this argument and, by extension, broader claims about the impact of political institutions on economic development. Building on a recent analysis of total factor productivity growth in African agriculture, we find that the introduction of competitive presidential elections in the last decades of the $20^{\text {th }}$ Century appears to have altered political incentives, resulting in policy reforms that have enhanced the performance of farmers. 


\section{Introduction}

In the later decades of the $20^{\text {th }}$ Century, political institutions in Africa changed. Prior to the late 1980s, open competition for national office was rare: politicians became heads of state either by launching military coups or by consolidating their political backing within the ruling party. Subsequently, most heads of state were instead chosen in elections contested by rival parties that competed to capture political support from a majority of the national electorate. ${ }^{2}$ On average, one third of Africa's people work in farming and $70 \%$ of its population resides in rural settings. The late-century introduction of electoral competition thus led to the enfranchisement of a rural electorate.

In the decades after independence, agriculture - the largest single sector in most African countries - virtually collapsed (World Bank 1981), foreshadowing and accelerating Africa's subsequent economic decline; its current revival has lent impetus to Africa's economic recovery. It is our claim that the reform of political institutions and the consequent enfranchisement of Africa's farmers influenced the performance of its rural sector, thereby shaping the continent's economic trajectory.

\footnotetext{
${ }^{2}$ For reviews of this political transition, see Widner, J., Ed. (1994). Economic Change and Political Liberalization in Sub-Saharan Africa. Baltimore MD, Johns Hopkins University Press; Bratton, M. and N. van de Walle (1997). Democratic Experiments in Africa. Cambridge, Cambridge University Press; ; Jospeh, R., Ed. (1998). State, Conflict and Democracy in Africa Boulder, Lynne Rienner; and Bates, R. (2009). Political Reform. The Political Economy of Economic Growth in Africa, 1960-2000. B. J. Ndulu, S. O'Connell, R. Bates, P. Collier and C. Saludo. Cambridge, Cambridge University Press.
} 
Figure 1 documents the nature and magnitude of political change in Africa. Classifying political systems along a 6-point scale that captures the level of electoral competition, the figure depicts the striking movement towards competitive politics ${ }^{3}$. In the 1970s, the mean lay below 3 ; by the 21st century, it lay above 6 , indicating a significant shift from authoritarian to competitive electoral systems.

Figure 2 highlights the challenge to which this paper responds. It compares the rate of growth in total factor productivity in the agricultural sectors of 34 states, 1961-2007, differentiating between those whose political institutions did and did not allow for electoral competition when choosing the head of state. On average, the figure suggests, countries with electoral competition experienced a growth of total factor productivity of $1.04 \%$ in their agricultural sector, while the average rate was $0.48 \%$ per year in countries without. $^{4}$

This paper probes the relationship between political institutions and economic performance by exploring the relationship between political reform and rural revival in Africa.

\footnotetext{
${ }^{3}$ For details of this index (Executive Index of Electoral Competition, EIEC, in Beck and Clarke, 2001), consult the online Appendix.

${ }^{4}$ As discussed in the online Appendix, countries with scores of 6 or above on the EIEC scale (described below) were counted as possessing electoral competition. The difference is significant at P-.0007 using a one-tailed t-statistic.
} 
Figures 1 and 2 Near Here

\section{The Literature}

Our paper contributes to three literatures: The first addresses the impact of political reform in Africa; the second, "urban bias" in the developing world; and the last, "the new institutionalism".

The first literature is best exemplified by the recent papers by Stasavage (2005) and Kudamatsu (2007). Working with data from 44 African countries, 1980-1996, Stasavage (2005) finds that governments chosen in elections openly contested by rival political parties spend more on primary education. Political reform led to higher levels and more geographically dispersed service delivery, he contends. Whereas urban dwellers may have had access to secondary and tertiary schooling, rural dwellers often lacked access even to primary schools. Stasavage therefore interprets the expansion of primary education after the re-introduction of competitive elections as a response to the needs - and demands -- of the rural electorate.

Working with household-level data from 28 African countries, Kudamatsu (2007) finds lower levels of infant and neo-natal mortality for children born following the introduction of competitive elections. As did Stasavage (2005), he attributes the change to improvements in service delivery, as politicians respond to the need to secure votes from an enfranchised citizenry. 
Note that (Stasavage 2005) relates institutional change to changes in educational policy, but not to changes in educational achievement, whereas (Kudamatsu 2007) relates political change to changes in health outcomes, but not to changes in health policy. By exploring the impact of institutional change on both policy reform and economic performance, this article combines their agendas.

Writing in the 1970s, Michael Lipton (Lipton 1977) exposed the manner in which public policies in South Asia conferred benefits upon urban dwellers while imposing costs upon those living in the rural areas. Pursuing this theme in Africa, (Bates 1981) noted the prevalence of similar policies and argued that the ability of Africa's governments to favor the urban areas depended upon their ability to demobilize the rural electorate. This paper seeks to advance the study of urban bias by observing the changes that resulted when that electorate was reenfranchised.

Lastly, the "new institutional economics" now shapes the study of economic history (North, Wallace et al. 2009) and development (Harriss, Hunter et al. 1995; Acemoglu and Robinson 2012). Economic development, it argues, is promoted or retarded by the nature of the institutions within which the economy inheres. Drawing on the evidence generated by recent changes in political institutions Africa, this paper offers a test of this claim.

Section 3 lays out our basic argument. Sections 4 and 5 explore the relationship between institutional reform policy choice, and productivity growth in agriculture. Section 6 concludes.

\section{The General Argument}


The relationship between political reform and economic change in developing countries can be derived from well-established insights into the consumption behavior of poor persons and the structure of their economies on the one hand and from the logic of collective action and party competition on the other.

Engel's law holds that as income rises, the proportion of income spent on food declines; the income elasticity of food consumption is less than unity. From this micro-level regularity a macro-level implication follows: that economic development implies structural change (Kuznets 1966; Chenery and Taylor 1968; Anderson and Hayami 1986; Lindert 1991; Matsuyama 1992). When people are poor, a large percentage of their total expenditure will be devoted to food; absent foreign trade and significant economies of scale in farming, the rural sector therefore will be large. But when people earn higher incomes, the percentage spent on food will be less and, absent a comparative advantage in global markets, the rural sector will then comprise a smaller portion of the economy.

Poor countries therefore exhibit a characteristic political-economic geography. The majority of the population works in farming; it lies widely scattered, each member producing but an infinitesimal percentage of the total agricultural output. A small portion of the population - often less than $10 \%$-- works in manufacturing and service provision and dwells in towns. Because government policies often favor large investments and because of economies of scale in manufacturing, urban firms are often few in number and large in size, and a significant percentage of the urban dwellers therefore derive their incomes from a small number of employers (Little, Scitovsky et al. 1970; Little 1982; for an African case, see Kaplinsky 1978). While those who farm are thus dispersed, economically and geographically, those who 
earn their incomes in the urban sector are not. Spatially, they are concentrated in a few settlements and economically they often labor in enterprises sufficiently large to dominate their markets.

The political implications are immediate and ironic and follow from the logic of collective action (Olson 1971, 1985): In countries with large agricultural populations, farmers are weak lobbyists. Being small, village producers rationally refrain from expending effort in attempts to influence agricultural prices; not so urban interests, which stand large in their markets. Being widely scattered, farmers face high costs of organizing; concentrated in towns, urban interests find it less expensive to do so. Urban interests therefore hold a relative advantage as lobbyists in less developed economies. In so far as government policy is influenced by organized groups, in countries with large agricultural sectors, it therefore tends to be adverse toward the interests of farmers (Olson 1971 and 1985; Bates 1981).

The result is a choice of public policies that, taken together, constitute "urban bias," or measures that privilege the incomes of the urban sector at the expense of the rural. Under pressure from urban interests, governments adopt trade policies that protect domestic markets for urban manufacturers while leaving the market for agricultural products open to imports from abroad. The overvaluation of currencies cheapens imports of foreign foodstuffs and lowers the earnings of exporters of cash crops. Government regulations limit exports of raw materials, compelling farmers to sell cotton, vegetables, fruits, and other products to local processors at prices below those that they could secure were they to ship them to foreign buyers. In these and other ways governments intervene so as to shift relative prices in favor of consumers and against the producers of agricultural products. 
Thus the standard account of urban bias. Central to this interpretation is a political assumption: interests, it assumes, gain representation solely by lobbying. But what if we now introduce competitive elections? Where representation is achieved through electoral channels and where rural dwellers constitute a large segment of the voting population, then politicians have an incentive to cater to the interests of farmers. The very factors that render farmers weak lobbyists - that they are numerous and spatially dispersed - render them attractive to those competing for an electoral majority (Varshney 1995). The search for political majorities should therefore encourage politicians to resist the political pressures emanating from urban consumers and to champion policies that cater to the interests of the countryside.

Many African economies conform to the conditions that underpin the above argument. Their mean income in is less than $\$ 1,000$ per annum (constant $\$$ US2000) and in most countries agriculture remains the largest single industry, employing nearly a third of the labor force and harboring nearly three quarters of the population. By the logic of the argument advanced thus far, we should therefore expect to see the reintroduction of party competition and majoritarian politics leading to the adoption of policies that strengthen the incentives for farming.

\section{Initial Evidence}

To explore this possibility, we advance two kinds of evidence. The first is bivariate and addresses (in Figure 1) the relationship between institutional reform and policy choice and (in Figure 2) the relationship between policy choice and economic performance. The second is multivariate and is presented in the section that follows.

\section{Political Reform and Public Policy}


In Figure 3, an index of political institutions runs along the x-axis and measures of government policy appear on the $y$-axis. The figure suggests that differences in political institutions bear a significant relationship with differences in public policies ${ }^{5}$ and in the way expected, given the argument advanced above.

Figure 3 Near Here

Institutions

As a measure of institutions, Figure 3 (following Figure 1) employs a scale known as EIEC (Executive Index of Electoral Competition). Developed by Ferree and Singh (2002) and subsequently amended and adopted by the World Bank for its Database of Political Institutions, the measure indicates the level of competition attendant the choice of chief executive. ${ }^{6}$

\footnotetext{
${ }^{5}$ In each of the regressions that overlay the scatter plots in Figure 3, the coefficient on the measure of electoral competition is significant at conventional levels of significance.

${ }^{6}$ See Beck, T., G. Clarke, et al. (2001). "New Tools and New Tests in Comparative Political Economy: The Database of Political Institutions." World Bank Economic Review. Bates, R. H., K. Ferree, et al. (1996). Toward the Systematic Study of Transitions. Development Discussion Paper No. 256. Cambridge MA, Harvard Institute for International Development. Ferree, K. and S. Singh (1999). Institutional Change and Economic Performance in Africa, 1970-1995. Annual Meetings of the American Political Science Association, Atlanta.
} 
We recast this index to form a dummy variable that takes the value 1 when the candidates from opposing parties campaigned for the presidency and 0 otherwise. ${ }^{7}$. We label the first set of governments as "competitive" and the second as "non-competitive" or, more loosely, "authoritarian". ${ }^{8}$ We call this dummy variable ELECOMP67.

To provide a robustness check, in the regressions that follow, we also employ the variable POLCOMP as a measure of political competition. The variable is described in the online Appendix and discussed in greater detail in (Jaggers and Marshall, 2000). Based on the descriptions of the variable that appear in the POLITY codebook $^{9}$, we consider observations that fall in the range 9 or above as "competitive" and those that fall at 8 or below as "noncompetitive" and refer to the variable as POLCOMP910. ${ }^{10}$

\footnotetext{
${ }^{7}$ In practice, this means we assign a 1 to all country years when the EIEC index is 6 or greater and 0 otherwise. For further details, see the online Appendix.

${ }^{8}$ As discussed below, we explore the use of other cut points as well.

${ }^{9}$ http://www.systemicpeace.org/inscr/p4manualv2010.pdf.

${ }^{10}$ We have varied the cut-points to assess the robustness of our findings. Those based on POLCOMP remained significant when we reduced the cutoff to 8 . There are only 9 observations of POLCOMP $=10$ in the sample, precluding us from testing a POLCOMP dummy limited to 10 s. Increasing the EIEC cutoff to 7 alone continued to generate significant results when analyzing agricultural output. When addressing TFP growth or RRA, an EIEC dummy limited to 7s retains the signs reported below, but the estimates are imprecise. The sample includes no observations of EIEC equal to 4 or 5 , precluding tests with a cutoff below our baseline of 6 .
}

Some readers have challenged our use of POLCOMP, arguing that we should employ the Democracy indicator from Polity IV instead. POLCOMP provides a measure of political competition, which is the specific focus of our 


\section{Public Policies}

Figure 3 contains data on roads, education, and agricultural research. Their relevance to the fortunes of farmers requires little discussion. Not so the data on rural bias.

As a measure of sectoral bias, we employ the Relative Rate of Assistance (RRA), calculated by Anderson (2010). The measure reflects the manner in which government intervention in markets shifts relative prices between agricultural and non-agricultural commodities and is calculated as the ratio of the impact policy interventions on the prices of goods made in the agricultural and non-agricultural sectors. The imposition of an ad valorem tariff on imports of manufactured goods, for example, would generate an increase in the domestic prices of manufactured goods and trigger a decrease in the RRA, thus signaling a shift in relative prices against farmers.

\section{Economic Performance}

As one measure of economic performance, we employ Block's (2010) calculation of the total value of agricultural output. After correcting for changes in prices, the measure records the extent to which farmers have altered their production, as by hiring more labor, clearing more land, or otherwise channeling more resources into farming. As a second, we employ his measure of total factor productivity (TFP), which provides a more restrictive and economically

hypothesis. In contrast, the democracy indicator is affected by other factors, such as the nature of the limits on executive power. Nonetheless, repeating our specifications with a binary version of that democracy indicator yields results that are similar to those presented here. These additional results are available in the on-line appendix. 
more meaningful measure of economic performance. TFP rises when output increases even when the quantity and quality of the factors of production remain constant. When measured by TFP, then, increases in output reflect the adoption of improved technologies and the greater efficiency of producers. Given diminishing returns, it is the growth of productivity, not the accumulation of productive factors, that in the long run leads to higher income. For that reason, TFP constitutes our principal measure of economic performance. ${ }^{11}$

\section{Policy Change and Economic Performance}

The Figure 4 demonstrates the relationship between our measure of urban bias (RRA) and changes in TFP. The differences in the patterns of TFP growth rates when controlling for RRA (versus the baseline specification which excludes RRA) suggest the magnitude of the impact of urban bias. The difference in the mean rates of change in Total Factor Productivity in agriculture is significant at greater than the .10 -level. ${ }^{12}$

${ }^{11}$ Our estimates for the growth of total factor productivity (TFP) are drawn from the work of Block (2010) who combines data from 44 countries over 46 years (1961-2007) Block derives his estimates from an aggregation of crop-specific outputs in each country based on commodity prices specific to the countries included in the sample. From these data, he calculated Paasche indices, applying to all years the prices from the final year to avoid estimates spuriously resulting from increases in prices over time. For details, consult the online Appendix.

${ }^{12}$ Block (2010) first estimated the growth rate pattern of TFP, thereby creating baseline estimates (for the available sample), and then re-estimated that result while including an additional explanatory variable (in this case, RRA). The extent to which that added variable explains agricultural TFP growth (and the timing of its effect) is reflected in the difference in the resulting TFP growth rate paths. He then calculated the resulting percentage difference in the mean TFP growth rates over the entire period, with and without the additional explanatory 
Figure 4 Near Here

\section{Multivariate Estimates}

The data thus far suggest that countries governed by executives chosen through political competition are more likely to choose policies that favor farmers and that these choices are associated with differences in the performance of agriculture. Multivariate methods enable us to sharpen and to deepen our analysis. After describing in greater detail our key dependent variable - the rate of growth of agricultural TFP -- we apply such methods in an effort to explore the relationship between political change and economic performance.

\section{Political Reform and Economic Performance}

To identify the impact of electoral competition on agricultural productivity growth, we employ a difference-in-difference specification. Given that the treatment, institutional change, occurred at different times in different countries, our model takes the form of a fixed effects regression with individual year dummies:

$$
Y_{i t}=\alpha_{0 i}+\alpha_{1 i} t+\lambda_{t}+\delta D_{i t}+X_{i t}^{\prime} \beta+\varepsilon_{i t}
$$

where $Y_{i t}$ is either agricultural output or the growth rate of agricultural productivity in country $i$ in year $t, \alpha_{0 i}$ are time-invariant unobservable country effects, $\lambda_{t}$ are year dummies, $X$ is a

variable. The resulting shares of TFP growth explained by the added variables must be interpreted as upper bounds, for reasons explained in Block (2010). 
vector of observed covariates, $D_{i t}$ is a dummy equal to one for each country-year observation in which there is electoral competition, and $\delta$ provides a measure of the relationship between electoral competition and the growth of agricultural TFP (which we assume to be a constant). ${ }^{13}$ $\alpha_{1 i}$ is a country-specific trend coefficient multiplying the time trend $t$, which provides a test of the identifying assumption of common trends implicit in difference-in-difference specifications. $^{14}$

The results in Table 1 suggest that electoral competition is associated with increased agricultural output on the order of 7 to 9 percent. Columns 1 and 2 regress crop output against our two indicators of electoral competition, ELECOMP67 and POLCOMP910, alone, while columns 3 and 4 demonstrate the robustness of these relationships to the inclusion of additional covariates: civil conflict, the average level of electoral competition in bordering states, and rural population share. ${ }^{15}$ Civil conflict was endemic in late century Africa, with $40 \%$ of countries experiencing at least one year of civil war between 1960 and 2000. Noting their occurrence enables us to control for the possibility that political competition affects TFP growth through its impact on political stability (Snyder and Mansfield 2000). If electoral competition were to generate strong political or economic forces, then their impact could spill across

${ }^{13}$ We adjust all standard errors for clustering at the country level, in keeping with the cautions advocated by Bertrand, Duflo, and Mullainathan (2004) regarding serial correlation in difference-in-difference models.

${ }^{14}$ The inclusion of country-specific trends reinforces the identifying assumption of our difference-in-differences interpretation, and distinguishes our regressions from the otherwise similar specifications estimated by Stasavage (2005).

${ }^{15}$ All specifications include agricultural controls, as detailed in the table notes. 
political boundaries; by controlling for the lagged average of the degree of electoral competition in each country's neighbors, we control for this possibility as well. Lastly, rural population share relates closely to the level of development, other correlates of which themselves bear upon productive efficiency. By including a measure of the relative size of the rural population, we thereby control for the impact of these unobserved variables. In addition, all specifications include country-specific time trends to demonstrate the robustness of our identifying assumptions.

Table 1 Near Here

Table 2 replicates this estimation strategy using agricultural TFP growth as the dependent variable. Here, too, we find that electoral competition is associated with an acceleration of TFP growth of approximately 0.5 percentage points. Note that this finding is consistent with the evidence contained in Figure 2.

Table 2 Near Here

An additional threat to identification is the possibility that the putative effect (agricultural TFP growth) may precede the supposed treatment (political reform). To assess this possibility, we follow Angrist and Pischke (2009) who invoke a form of Granger causality: 


$$
Y_{i t}=\alpha_{i}+\lambda_{t}+\sum_{\tau=0}^{m} \delta_{-\tau} D_{i, t-\tau}+\sum_{\tau=1}^{q} \delta_{+\tau} D_{i, t+\tau}+X_{i t}^{\prime} \beta+\varepsilon_{i t}
$$

The model allows for $m$ lags (post-treatment effects) and $q$ leads (anticipatory effect). Figure 5(A) graphs the coefficient estimates of these post- and pre-treatment effects for $m=q=$ 4 leads and lags surrounding the year in which each country transitioned into a system of competitive elections. The results indicate no significant anticipatory effect on changes in agricultural productivity. The difference between the mean coefficients before and after political transition is 0.56 percentage points, a magnitude consistent with the estimates in Table 2.

Figure 5 Near Here

\section{Political Reform and Policy Choice}

Making use of the same difference-in-difference specification that we employed above, columns 1 and 2 in Table 3 suggest a positive relationship between our indicators of electoral competition and our measure of urban bias. ${ }^{16}$ The addition of country-specific trends in column 3 renders the coefficient of ELECOMP67 insignificant, however, although - as seen in column 4 - rendering that of POLCOMP910 more precisely estimated.

\footnotetext{
${ }^{16}$ Recall: Positive changes in RRA indicate less urban bias, that is, more favorable policies toward agriculture.
} 
While we believe the risk of reverse causality (in the sense that RRA would cause electoral competitiveness) is minimal, we remain keenly aware of the possible impact of excluded variables. In particular, pressure from the donor community could plausibly account for the co-variation of electoral competitiveness and policy support for domestic food producers. However, only in the case of column 5 is the participation in an IMF agreement significantly related to a shift in relative support for agriculture.

There remains an additional concern, however: that agreements with the IMF may not be randomly distributed across countries. In columns 7-8 we therefore estimate a two-stage model in which we, as do others (e.g. Easterly 2005), instrument for IMF agreements using each country's level of US military assistance and previous colonial status. ${ }^{17}$ As in the previous models, POLCOMP910 remains positive and statistically significant, suggesting that electoral competition improved incentives for African farmers. This conclusion is reflected, as well, in Figure $5(B)$, which illustrates the increase in RRA in the years before and after a transition into a competitive electoral system (indicated by POLCOMP910). ${ }^{18}$

\footnotetext{
${ }^{17}$ Easterly (2005) argues that US military assistance is indicative of the recipient as being a "friend of the donor," and thus a correlate of IMF agreements, while not affecting (in our case) agricultural price policy via any other channel. The F-tests of excluded instruments on 2SLS versions of the regressions on columns 7 and 8 are $8.6-$ suggesting the possibility of weak instruments. This is of secondary concern, however, as our primary focus is on the effect of electoral competition, rather than on the specific effect of IMF agreements.

${ }^{18}$ This Figure, too, is based on the estimation of equation (5), and reinforces the identifying assumption of our model.
} 
Table 3 Near Here

Insofar as our argument is valid, we would expect that the magnitude of the impact of electoral competition should vary with the relative size of the rural electorate. This implication provides additional opportunity for testing, and in Table 4 we interact rural population share with indicators of electoral competition, evaluating the partial derivatives at the $25^{\text {th }}, 50^{\text {th }}$ and $75^{\text {th }}$ percentiles of the sample distribution. ${ }^{19}$ In columns $1,2,4$, and 6 , the total effect of electoral competition on RRA increases with the rural population share, with the effect at the $75^{\text {th }}$ percentile approximately three times greater than that found at the $25^{\text {th }}$ percentile. This is the case with and without the inclusion of country-specific trends, and while instrumenting for our indicator of IMF agreements. Only in columns 7 and 8, where we both instrument for the IMF agreements and include country-specific trends, does this interaction effect disappear.

Table 4 Near Here

\section{Mediation Analysis}

Thus far we have demonstrated that agricultural TFP growth is higher in settings with electoral competition and that the effect operates at least in part through policy choices. To quantify the magnitude of this transmission effect, we apply mediation analysis (Imai, et.al. 2011), estimating three linear regressions:

\footnotetext{
${ }^{19}$ These points correspond to population shares of approximately 60, 70 and 80 percent, respectively.
} 


$$
\text { a) } Y_{i}=\alpha_{1}+\beta_{1} T_{i}+X_{i} \varphi_{1}+\varepsilon_{i 1}
$$

b) $\quad M_{i}=\alpha_{2}+\beta_{2} T_{i}+X_{i} \varphi_{2}+\varepsilon_{i 2}$

c) $Y_{i}=\alpha_{3}+\beta_{3} T_{i}+\gamma M_{i}+X_{i} \varphi_{3}+\varepsilon_{i 3}$

where $Y$ is the outcome variable (agricultural TFP growth), $T$ is the treatment variable (electoral competition), and $M$ is the mediating variable (RRA), and $X$ is a vector of control variables (including rural population share and the civil war dummy).

Equation 6 a can be thought of as corresponding to the specification underlying Table 2, in which $\hat{\beta}_{1}$ provides an estimate of the "total average treatment effect" (in Imai, et. al.'s terminology), with Equation $6 \mathrm{~b}$ corresponding to that underlying Table 3. Equation $6 \mathrm{c}$ closes this loop, allowing us to decompose that total average treatment effect into the average direct effect of the treatment on the outcome $\left(\hat{\beta}_{3}\right)$, and the mediating effect, or the extent to which the treatment variable operates through public policies. Note that the mediating effect and the direct effect sum to the total effect. The mediating effect is estimated as $\hat{\beta}_{2} \hat{\gamma}$ or, equivalently, $\left(\hat{\beta}_{1}-\hat{\beta}_{3}\right)$

Table 5 summarizes the results of our analysis. As before, we employ ELECOMP67 and POLCOMP910 as treatment variables. The mediating variable is RRA. The exercise thus measures the extent to which the effect of electoral competition on agricultural TFP growth operates through the mediating effect of electoral competition on agricultural price policy (RRA) as opposed to other channels. By including an interaction term between electoral competition and rural population share, we are able further to determine whether these effects are a positive function of rural population share (which we evaluate at the 25 th, 50th, and 75 th 
percentiles of its distribution). Columns 1-3 uses ELECOMP67 as the treatment variable. We find the total treatment effect of electoral competition on TFP growth is on the order of 1.5 percentage points. Note that while the total effect is a (slightly) declining function of rural population share, the extent to which the effect of political reform on TFP growth is mediated by RRA increases with the share of the rural population. At the 75th percentile of rural population share, nearly $14 \%$ of this total treatment effect is mediated through RRA. When we use POLCOMP910 as the treatment variable, these effects remain significant and increase in magnitude (columns $4-6$ ). In this instance, both the total treatment effect and the magnitude of the mediation effect are strongly positive functions of rural population share. ${ }^{20}$

That the direct effect of changes in political institutions is greater than the effect that runs through changes in policy suggests that the re-introduction of political competition affected rural producers through multiple channels. These may have included policies which affected the profitability of farming in ways other than relative prices, such as by increasing school enrolments, building roads, and introducing new seed varieties, for example. ${ }^{21}$ Field reports suggest that with democratization came other "non-policy" changes as well: a greater willingness to permit private merchants to purchase agricultural commodities and to sell consumer goods to farmers; to let non-governmental organizations operate in rural areas; and to allow freer communications, be it by pamphleting or FM radio, thereby promoting the more

${ }^{20}$ Data limitations again impact on our analysis. The anomalous estimate of the mediation effect's share of the total treatment effect in column 4 is an artifact of the small and statistically insignificant point estimate of the total treatment effect at the low level of rural population share.

${ }^{21}$ Lack of data prevented us from exploring these policies in the same manner as we did RRA. 
rapid exposure of bottlenecks in the provision of goods and services needed by farmers. Such sources of vitality, unleashed in rural communities at the same time as was greater competition for the votes of farmers, may help to account for the portions of the impact of political reform on the performance of farmers that our analysis has left unexplained.

Table 5 Near Here

\section{Conclusion}

This article re-examines the political foundations of economic development in Africa. In the period of authoritarian politics, Africa's leaders stood astride a narrow political base, consisting of organized interests largely lodged in urban centers: the government and its employees, the labor movement, and manufacturers with their attendant service industries. In response to threats to their welfare, members of this coalition pressed for measures to lower the prices of agricultural goods and policy makers responded as if finding credible threats of political protests should they fail to do so. Following the reintroduction of electoral competition, political leaders in many African countries found themselves in a new political environment: they now faced an electorate that was largely rural. It is our argument that their desire for office led them to alter their political strategies, resulting in adoption of economic policies more 
favorable to farmers. And in response to these changes in policy, it would appear, production increased and total factor productivity rose in rural Africa. ${ }^{22}$

${ }^{22}$ Among the possible challenges to this interpretation, one stands out: that we wrongly assume that rural voters engage in policy- or performance-based voting. We post our rejoinder to the online Appendix. 


\section{REFERENCES}

Acemoglu, D. and J. A. Robinson (2012). Why Nations Fail: The Progons of Power, Prosperity, and Poverty. New York, Crown Publishers.

Anderson, K. (2010). Distortions to Agricultural Incentives: A Global Perspective, 1955-2007. London, Palgrave Macmillan.

Anderson, K. and Y. Hayami (1986). The Political Economy of Agricultural Protection. London, Allen and Unwin.

Bates, R. (2009). Political Reform. The Political Economy of Economic Growth in Africa, 1960-

2000. B. J. Ndulu, S. O'Connell, R. Bates, P. Collier and C. Saludo. Cambridge, Cambridge University Press.

Bates, R. H. (1981). Markets and States in Tropical Africa. Berkeley and Los Angeles, University of California Press.

Bates, R. H., K. Ferree, et al. (1996). Toward the Systematic Study of Transitions. Development Discussion Paper No. 256. Cambridge MA, Harvard Institute for International Development.

Beck, T., G. Clarke, et al. (2001). "New Tools and New Tests in Comparative Political Economy: The Database of Political Institutions." World Bank Economic Review. Bertrand, M., E. Duflo, and S. Mullainathan, “How Much Should We Trust Differences-inDifferences Estimates?" The Quarterly Journal of Economics (2004) 119 (1): 249-275. Block, S. (2010). The Decline and Rise of Agricultural Productivity in Sub Saharan Africa Since 1961. Working Paper 16481. Cambridge MA, National Bureau of Economic Research. 
Bratton, M. and N. van de Walle (1997). Democratic Experiments in Africa. Cambridge, Cambridge University Press.

Chenery, H. B. and L. J. Taylor (1968). "Development Patterns: Among Countries and Over Time." Review of Economics and Statistics(November): 391-416.

Easterly, W. (2005). "What did Structural Adjustment Adjust? The Association of Policies and Growth with Repeated IMF and World Bank Adjustment Loans." Journal of Development Economics 76: 1-21.

Ferree, K. and S. Singh (1999). Institutional Change and Economic Performance in Africa, 19701995. Annual Meetings of the American Political Science Association, Atlanta.

Harriss, J., J. Hunter, et al., Eds. (1995). The New Institutional Economics and Third World Development. London and New York, 1995.

Imai, K., L. Keele, et al. (2010). Unpacking the Black Box: Learning about Causal Mechanisms From Experimental Observational Studies. Working Paper. Princeton, Department of Government.

Marshall, Monty G., and Keith Jaggers. 2002. Polity IV Dataset. [Computer file; version p4v2002] College Park, MD: Center for International Development and Conflict Management, University of Maryland Joseph, R., Ed. (1998). State, Conflict and Democracy in Africa. Boulder, Lynne Rienner. Kaplinsky, R., Ed. (1978). Readings on the Multinational Corporation in Kenya. New York, Oxford University Press. 
Krueger, A. O., M. Schiff, et al., Eds. (1992). The Political Economy of Agricultural Pricing

Policies, 5 vols. Baltimore, Published for the World Bank by Johns Hopkins University Press.

Kudamatsu, M. (2007). Has Democratization Reduced Infant Mortality in Sub-Saharan Africa?

Evidence from Micro Data. SSRN Discussion Paper No. 685. Stockholm, Stockholm University Institute for International Economic Studies

Kuznets, S. (1966). Modern Economic Growth. New Haven and London, Yale University Press. Lindert, P. H. (1991). Historical Patterns of Agricultural Policy. Agriculture and the State. P. Timmer. Ithaca, Cornell University Press.

Lipton, M. (1977). Why poor people stay poor: A study of urban bias in world development. London, Temple Smith.

Little, I. M. D., T. Scitovsky, et al. (1970). Industry and Trade in Some Developing Countries. Oxford, Oxford University Press.

Little, I. M. D. (1982). Economic Development. New York, Basic Books.

Matsuyama, K. (1992). "Agricultural Productivity, Comparative Advantage, and Economic Growth." Journal of Economic Theory 58: 317-334.

Ndulu, B. J. and S. O'Connell (2009). Policy Plus: African Growth Performance, 1960-2000. The Political Economy of Economic Growth in Africa, 1960-2000. B. J. Ndulu, S. O'Connell, R. Bates, P. Collier and C. Saludo. Cambridge, Cambridge University Press: 4-75.

Ndulu, B. J., S. A. O'Connell, et al. (2008). The Political Economy of Economic Growth in Africa, 1960-2000. New York, Cambridge University Press. 
North, D., J. Wallace, et al. (2009). Violence and Social Orders: A Conceptual Framework for Interpreting Human History. New York, Cambridge University Press.

North, D. C. (1981). Structure and Change in Economic History. New York, Norton.

North, D. C. and R. P. Thomas (1973). The Rise of the Western World. Cambridge, Cambridge University Press.

Olson, M. (1971). The Logic of Collective Action. New York, Schoken Books.

Olson, M. (1985). "Space, Agriculture, and Organization." Journal of Agricultural Economics 67(5): 928-937.

Snyder, J. and E. Mansfield (2000). From Voting to Violence: Democratization and Nationalist Conflict. New York, W.W.Norton.

Stasavage, D. (2005). "Democracy and Education Spending in Africa." American Journal of Political Science 49(2): 343-358.

Varshney, A. (1995). Democracy, Development and the Countryside. Cambridge, Cambridge University Press.

Widner, J., Ed. (1994). Economic Change and Political Liberalization in Sub-Saharan Africa. Baltimore MD, Johns Hopkins University Press.

World Bank. (1981). Accelerated Development in Sub-Saharan Africa: An Agenda for Action. Washington DC, The World Bank.

World Bank. (1986). Sub-Saharan Africa: From Crisis to Sustainable Development. Washington DC, The World Bank. 
World Bank. (1994). "Adjustment in Africa: Reforms, Results, and the Road Ahead." World Bank Policy Research Bulletin 5(2). 
Figure 1. Index of Political Competition

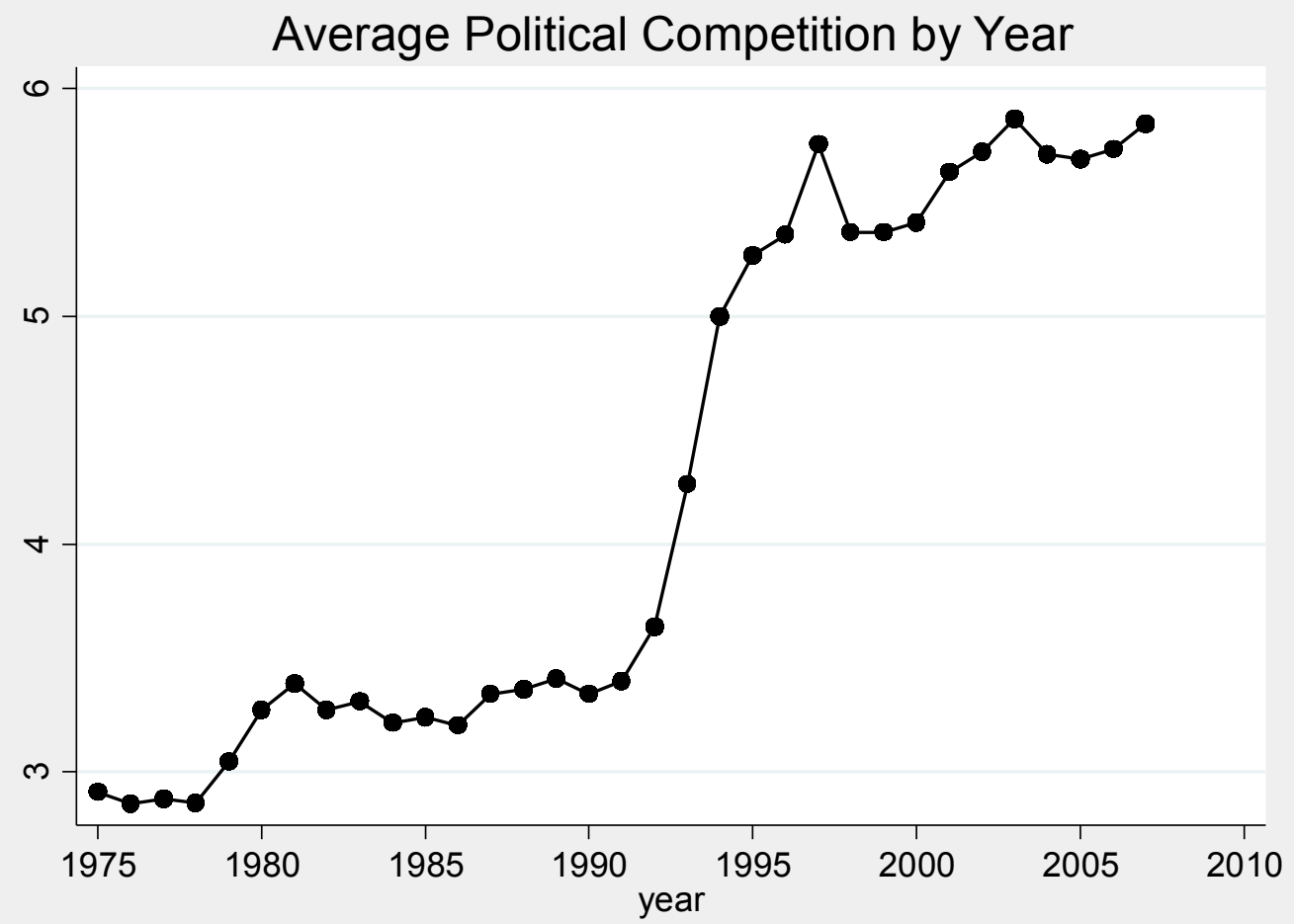

Source: World Bank, Database of Political Institutions (Beck and Clarke, 2001) 
Figure 2. Agricultural TFP Growth Profile for Country-Years With and Without Electoral Competition

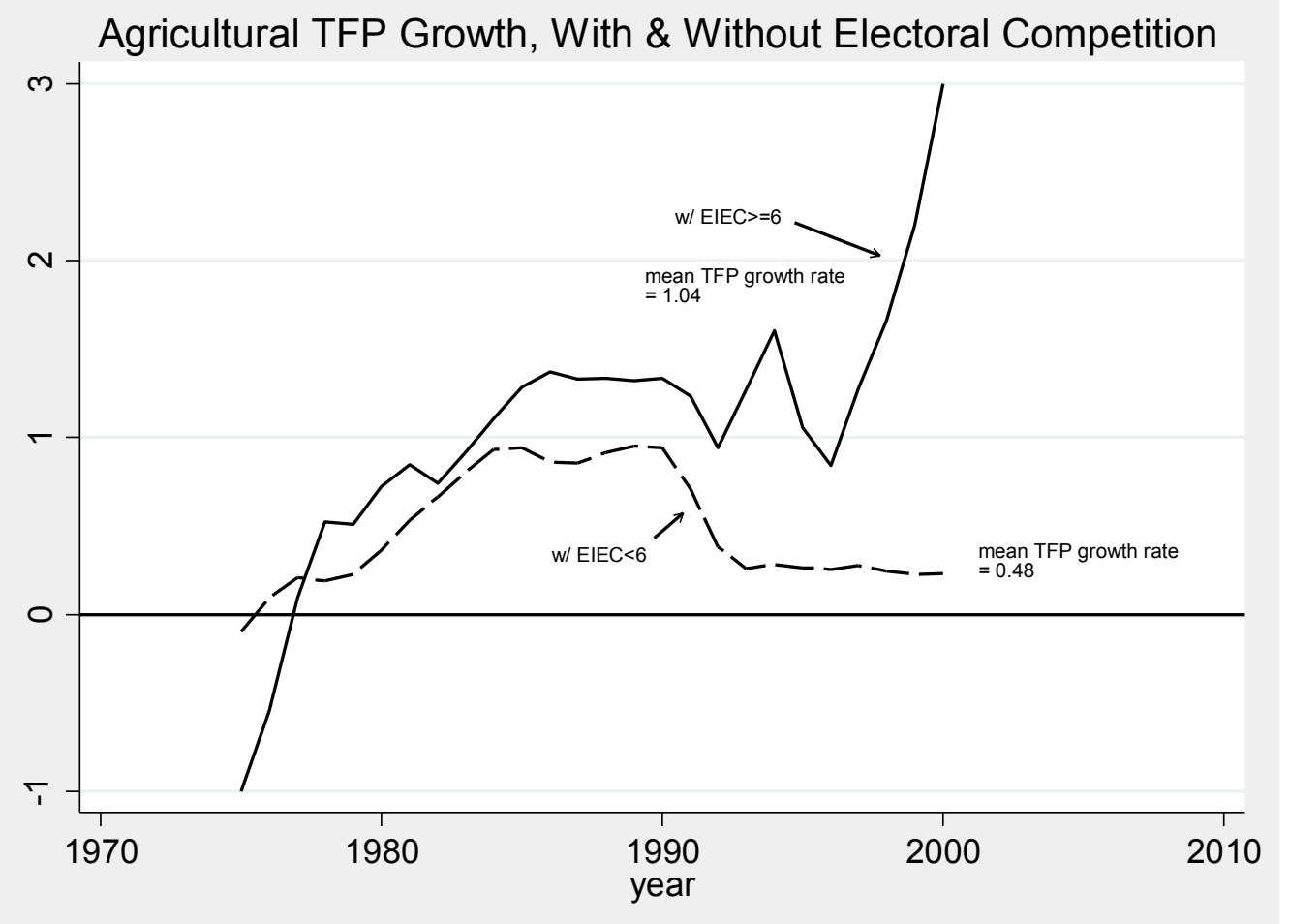

Source: (Block 2010) 
Figure 3. Public Policies and Electoral Competition

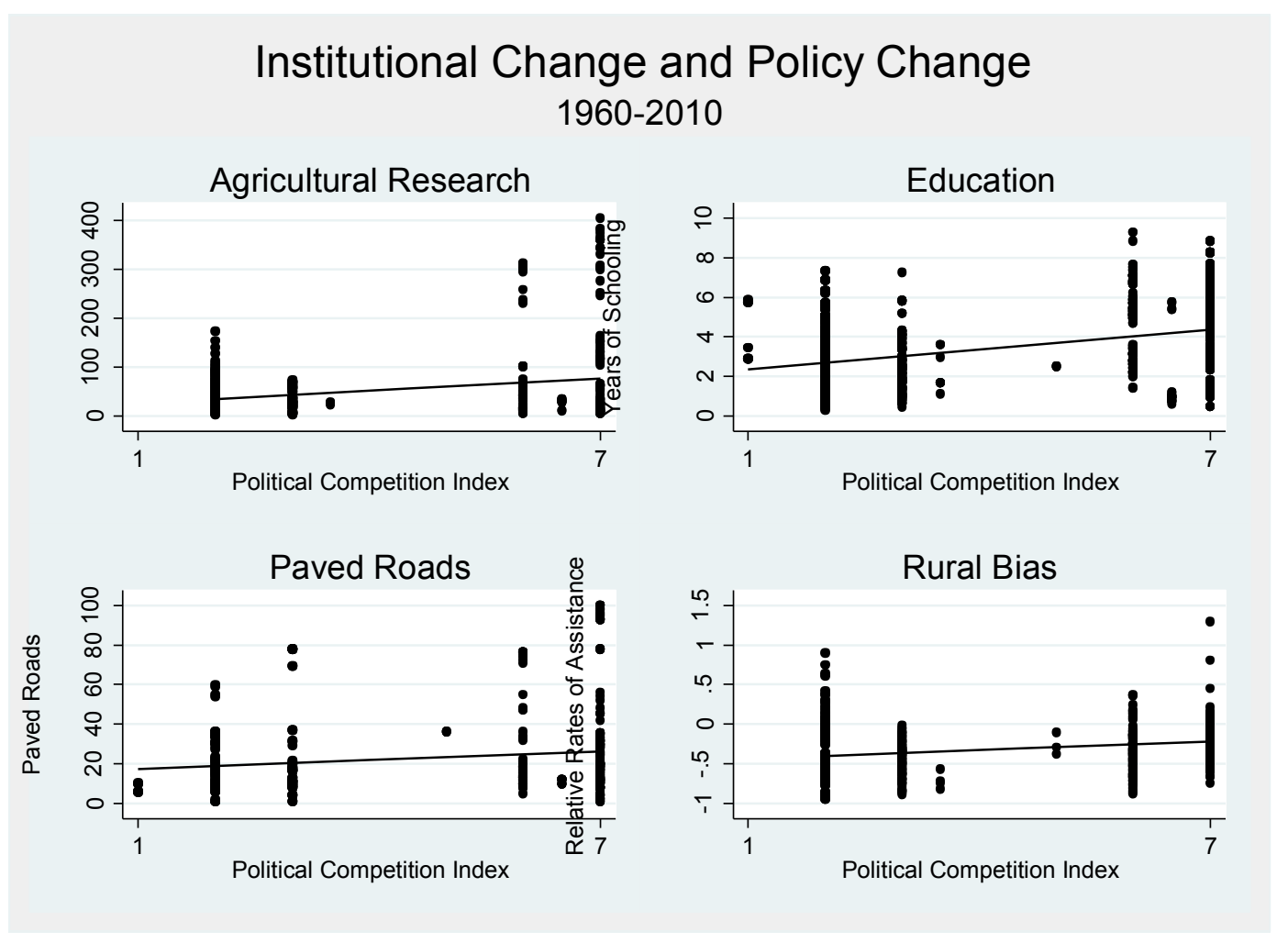


Figure 4. The Effect of Relative Rate of Assistance on Agricultural TFP Growth

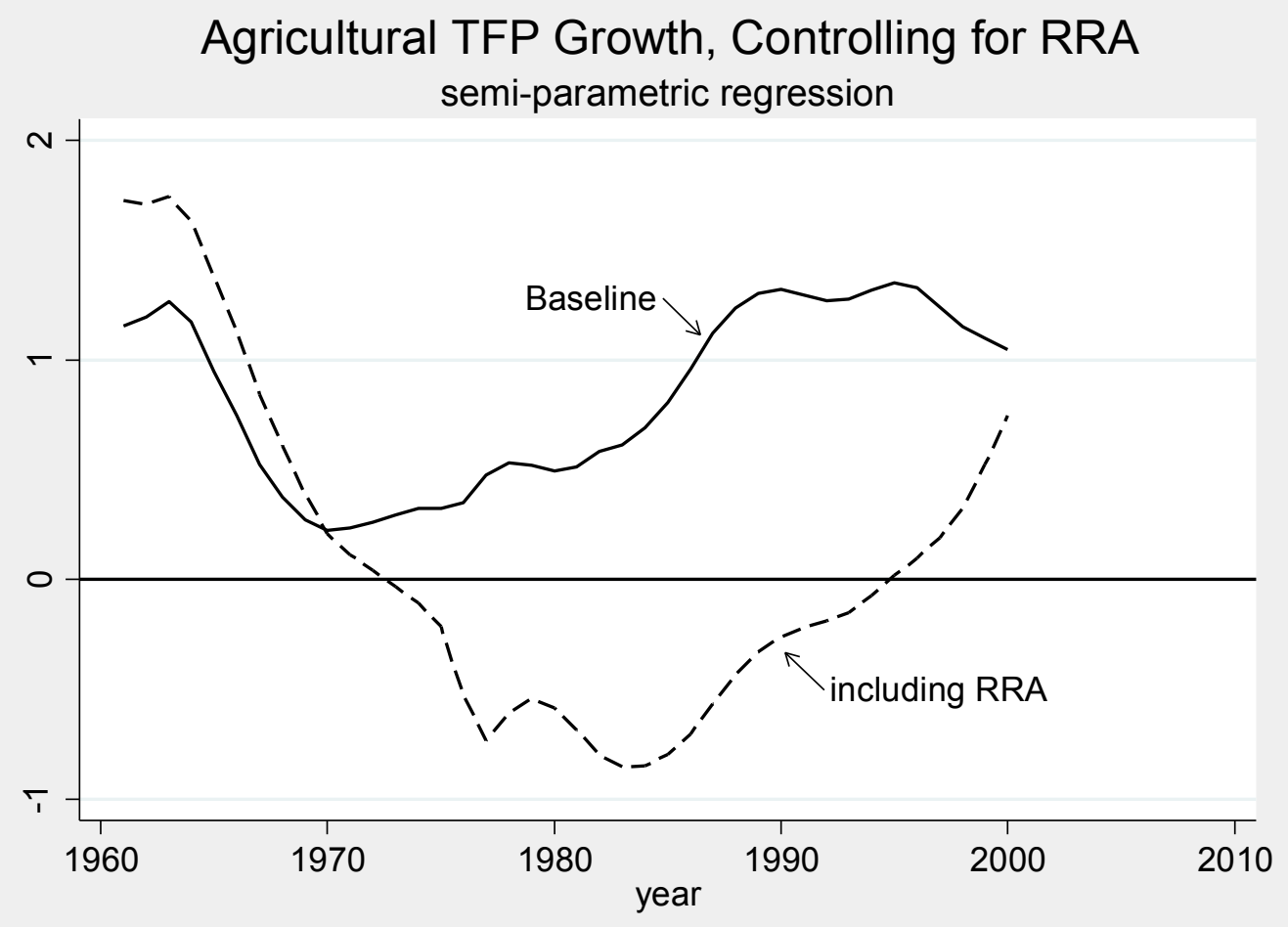


Figure 5. Before \& After Transition to Competitive Elections

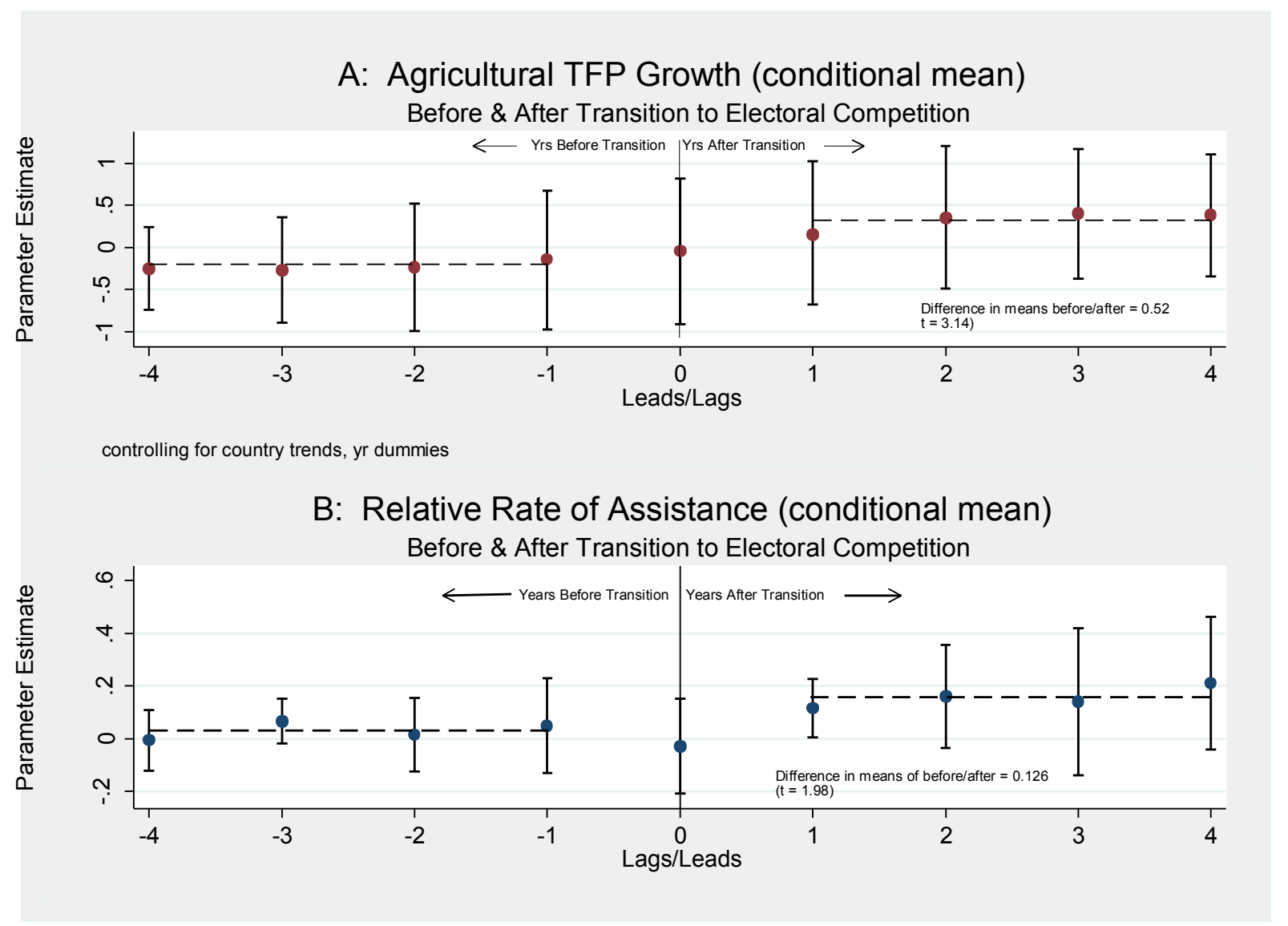


Table 1. Effect of Electoral Competition on Agricultural Output

\begin{tabular}{|c|c|c|c|c|}
\hline VARIABLES & $\begin{array}{c}\text { (1) } \\
\text { log_agric output }\end{array}$ & $\begin{array}{c}\text { (2) } \\
\text { log_agric output }\end{array}$ & $\begin{array}{c}\text { (3) } \\
\text { log_agric output }\end{array}$ & $\begin{array}{c}(4) \\
\text { log_agric output }\end{array}$ \\
\hline \multirow[t]{2}{*}{ ELECOMP67 $7^{\mathrm{a}}$} & $0.0717^{* *}$ & & $0.0755^{* *}$ & \\
\hline & $(0.0287)$ & & $(0.0293)$ & \\
\hline \multirow[t]{2}{*}{ POLCOMP910 } & & $0.0999 * *$ & & $0.0874 *$ \\
\hline & & $(0.0459)$ & & $(0.0478)$ \\
\hline \multirow[t]{2}{*}{ Rural Pop. Share } & & & $-0.0357^{*}$ & -0.0341 \\
\hline & & & (0.0199) & $(0.0215)$ \\
\hline \multirow[t]{2}{*}{ Civil War dummy } & & & 0.00884 & 0.0208 \\
\hline & & & $(0.0232)$ & $(0.0229)$ \\
\hline \multirow{2}{*}{$\begin{array}{l}\text { Avg EIEC of } \\
\text { neighbors (t-1) }\end{array}$} & & & 0.00426 & 0.00527 \\
\hline & & & $(0.0120)$ & $(0.0131)$ \\
\hline \multirow[t]{2}{*}{ Constant } & 7.207 & 4.579 & $57.41 *$ & 53.11 \\
\hline & (18.05) & (17.89) & (33.31) & $(35.47)$ \\
\hline Observations & 605 & 605 & 605 & 605 \\
\hline R-squared & 0.716 & 0.716 & 0.729 & 0.727 \\
\hline Country FE & YES & YES & YES & YES \\
\hline Year FE & YES & YES & YES & YES \\
\hline Country Trends & YES & YES & YES & YES \\
\hline
\end{tabular}

Robust standard errors (clustered at country level) in parentheses $* * * p<0.01,{ }^{* *} p<0.05,{ }^{*} p<0.1$

Notes: ${ }^{a}$ ELECOMP67 is a dummy variable $=1$ if EIEC $\geq 6 .{ }^{b}$ POLCOMP910 is a dummy variable $=1$ if

POLCOMP $\geq 9$. All specifications also include controls for rainfall, share of irrigated land, years schooling for the population, log of population, and log of arable land, and a full set of year dummies. 
Table 2. Effect of Electoral Competition on Agricultural TFP Growth

\begin{tabular}{lllll}
\hline & $(1)$ & $(2)$ & $(3)$ & $(4)$ \\
\hline ELECOMP67 & $0.585^{* *}$ & & $0.544^{* *}$ & \\
POLCOMP910 & $(0.226)$ & & $(0.210)$ & $0.439^{*}$ \\
& & $0.568^{*}$ & & $(0.263)$ \\
Rural Pop. Share & & $(0.306)$ & & -0.0344 \\
& & -0.0463 & $(0.205)$ \\
Civil War dummy & & & $(0.199)$ & -0.111 \\
& & & -0.192 & $(0.160)$ \\
Avg EIEC of & & $(0.168)$ & 0.221 \\
neighbors (t-1) & & & 0.203 & $(0.138)$ \\
Constant & -48.62 & $-77.16^{* * *}$ & $(0.127)$ & 9.858 \\
& $(32.08)$ & $(26.37)$ & 48.13 & $(266.9)$ \\
Observations & 605 & 605 & $(265.3)$ & 605 \\
R-squared & 0.668 & 0.661 & 605 & 0.672 \\
Number of ctys & 27 & 27 & 0.679 & 27 \\
Country FE & YES & YES & 27 & YES \\
Year FE & YES & YES & YES & YES \\
Country Trends & YES & YES & YES \\
\hline
\end{tabular}

Robust standard errors (clustered at the country level) in parentheses.

$* * * p<0.01, * * p<0.05, * p<0.1$ 
Table 3. Effect of Electoral Competition on Relative Rate of Assistance (DiD specification)

\begin{tabular}{|c|c|c|c|c|c|c|c|c|}
\hline & $(1)$ & $(2)$ & $(3)$ & $(4)$ & $(5)$ & (6) & $(7)$ & (8) \\
\hline \multirow[t]{2}{*}{ VARIABLES } & $\mathrm{FE}$ & $\mathrm{FE}$ & FE & $\mathrm{FE}$ & $\mathrm{FE}$ & $\mathrm{FE}$ & FE-2SLS & FE-2SLS \\
\hline & \multicolumn{8}{|c|}{ Dependent Variable: Relative Rate of Assistance } \\
\hline \multirow[t]{2}{*}{ ELECOMP67 } & $0.103^{*}$ & & 0.000303 & & 0.00333 & & -0.00818 & \\
\hline & $(0.0576)$ & & $(0.0366)$ & & $(0.0341)$ & & $(0.0357)$ & \\
\hline \multirow[t]{2}{*}{ POLCOMP910 } & & $0.177^{\dagger}$ & & $0.157 * * *$ & & $0.152 * * *$ & & $0.116^{*}$ \\
\hline & & $(0.106)$ & & $(0.0472)$ & & $(0.0481)$ & & $(0.0691)$ \\
\hline \multirow[t]{2}{*}{ Rural Pop Shr } & -0.000144 & 0.00128 & 0.0134 & 0.0207 & 0.00987 & 0.0172 & 0.0104 & 0.0240 \\
\hline & $(0.0107)$ & $(0.0106)$ & (0.0189) & $(0.0181)$ & $(0.0180)$ & $(0.0177)$ & $(0.0270)$ & $(0.0306)$ \\
\hline Civil War & -0.0292 & 0.0163 & $-4.55 e-05$ & 0.0105 & 0.0103 & 0.0207 & -0.0121 & -0.0113 \\
\hline dummy & $(0.0769)$ & $(0.0693)$ & $(0.0403)$ & (0.0379) & $(0.0427)$ & $(0.0393)$ & $(0.0373)$ & $(0.0362)$ \\
\hline Under IMF & & & & & $0.0579 *$ & 0.0544 & 0.138 & 0.114 \\
\hline Agreement & & & & & $(0.0301)$ & $(0.0315)$ & (0.199) & $(0.204)$ \\
\hline \multirow[t]{2}{*}{ Constant } & -0.372 & -0.474 & -26.21 & $-30.90 *$ & -20.24 & -25.29 & -18.16 & -29.11 \\
\hline & $(0.819)$ & $(0.813)$ & $(18.48)$ & $(17.03)$ & (17.09) & $(16.27)$ & $(33.56)$ & $(36.30)$ \\
\hline Observations & 401 & 401 & 401 & 401 & 401 & 401 & 261 & 261 \\
\hline R-squared & 0.230 & 0.242 & 0.466 & 0.479 & 0.474 & 0.486 & & \\
\hline $\begin{array}{l}\text { Number of } \\
\text { countries }\end{array}$ & 15 & 15 & 15 & 15 & 15 & 15 & 14 & 14 \\
\hline Country FE & YES & YES & YES & YES & YES & YES & YES & YES \\
\hline Year FE & YES & YES & YES & YES & YES & YES & YES & YES \\
\hline Country- & NO & NO & YES & YES & YES & YES & YES & YES \\
\hline Trends & & & & & & & & \\
\hline
\end{tabular}

Note: Negative values of RRA indicate that government policies favor consumers of agricultural products, i.e. the presence of urban bias; a positive increase indicates a shift in favor of agricultural producers. 
Table 4. Effect of Electoral Competition on Relative Rate of Assistance, as a function of Rural Population Share

\begin{tabular}{|c|c|c|c|c|c|c|c|c|}
\hline & (1) & (2) & (3) & (4) & (5) & (6) & (7) & (8) \\
\hline VARIABLES & FE & $\mathrm{FE}$ & $\mathrm{FE}$ & FE & FE-2SLS & FE-2SLS & FE-2SLS & FE-2SLS \\
\hline \multirow[t]{2}{*}{ ELECOMP67 } & $-0.372 *$ & & -0.252 & & $-0.501 * *$ & & -0.233 & \\
\hline & $(0.182)$ & & $(0.257)$ & & $(0.230)$ & & $(0.243)$ & \\
\hline \multirow{2}{*}{ Elecomp x rurpopshr } & $0.00632 * *$ & & 0.00360 & & $0.00690 * *$ & & 0.00300 & \\
\hline & $(0.00286)$ & & $(0.00344)$ & & $(0.00330)$ & & $(0.00332)$ & \\
\hline \multirow[t]{2}{*}{ POLCOMP910 } & & -0.364 & & $-0.550 *$ & & -0.414 & & 0.273 \\
\hline & & $(0.215)$ & & $(0.296)$ & & $(0.558)$ & & $(0.457)$ \\
\hline \multirow[t]{2}{*}{ polcomp910xrurpopshr } & & $0.00790^{*}$ & & $0.0105^{* *}$ & & 0.00782 & & -0.00272 \\
\hline & & $(0.00371)$ & & $(0.00420)$ & & $(0.00784)$ & & $(0.00626)$ \\
\hline \multirow[t]{2}{*}{ Rural Pop. Share } & -0.00265 & -0.000366 & 0.00680 & $0.0158 * *$ & -0.00993 & 0.00392 & -0.00220 & 0.00881 \\
\hline & $(0.0101)$ & $(0.00623)$ & $(0.0177)$ & $(0.00718)$ & $(0.00758)$ & $(0.00604)$ & $(0.0342)$ & (0.0104) \\
\hline \multirow[t]{2}{*}{ Civil War dummy } & -0.00268 & 0.0196 & 0.0142 & 0.00132 & -0.0151 & 0.0162 & -0.0190 & -0.0200 \\
\hline & $(0.0531)$ & $(0.0400)$ & $(0.0422)$ & $(0.0267)$ & $(0.0378)$ & $(0.0486)$ & $(0.0354)$ & $(0.0464)$ \\
\hline \multirow[t]{2}{*}{ Under IMF Agreement } & $0.121 * * *$ & $0.0805 * * *$ & $0.0501^{*}$ & 0.0478 & $0.264 *$ & 0.366 & 0.143 & 0.257 \\
\hline & $(0.0285)$ & $(0.0181)$ & $(0.0273)$ & $(0.0274)$ & $(0.156)$ & $(0.256)$ & $(0.190)$ & $(0.218)$ \\
\hline \multirow[t]{2}{*}{ Constant } & -0.0435 & -0.194 & -25.57 & $-20.69 * *$ & 0.611 & -0.490 & -19.58 & -3.022 \\
\hline & $(0.668)$ & $(0.521)$ & $(17.74)$ & $(8.269)$ & $(0.514)$ & $(0.532)$ & $(33.57)$ & $(19.12)$ \\
\hline \multicolumn{9}{|c|}{ Total Effect of Electoral Competition Evaluated with Rural Population Share at: } \\
\hline \multirow[t]{2}{*}{$25^{\text {th }}$ percentile } & 0.014 & $0.118^{*}$ & -0.032 & 0.088 & -0.080 & 0.063 & -0.049 & 0.107 \\
\hline & $(0.042)$ & $(0.059)$ & $(0.056)$ & $(0.071)$ & $(0.046)$ & $(0.092)$ & $(0.051)$ & $(0.099)$ \\
\hline \multirow[t]{2}{*}{$50^{\text {th }}$ percentile } & 0.067 & $0.185^{* *}$ & -0.001 & $0.177^{* *}$ & -0.021 & $0.130 * *$ & -0.024 & 0.084 \\
\hline & $(0.047)$ & $(0.075)$ & $(0.037)$ & $(0.063)$ & $(0.039)$ & $(0.052)$ & $(0.036)$ & $(0.071)$ \\
\hline \multirow[t]{2}{*}{$75^{\text {th }}$ percentile } & $0.137^{*}$ & $0.272 * *$ & 0.039 & $0.293 * * *$ & 0.055 & $0.217^{* *}$ & 0.009 & 0.054 \\
\hline & $(0.067)$ & $(0.107)$ & $(0.041)$ & $(0.080)$ & $(0.055)$ & $(0.092)$ & $(0.044)$ & $(0.087)$ \\
\hline Observations & 432 & 548 & 432 & 548 & 279 & 313 & 279 & 313 \\
\hline R-squared & 0.314 & 0.287 & 0.471 & 0.412 & & & & \\
\hline Number of ccode & 15 & 15 & 15 & 15 & 15 & 14 & 15 & 14 \\
\hline Country FE & YES & YES & YES & YES & YES & YES & YES & YES \\
\hline Year FE & YES & YES & YES & YES & YES & YES & YES & YES \\
\hline Country-Trends & NO & NO & YES & YES & NO & NO & YES & YES \\
\hline
\end{tabular}

Robust standard errors (clustered at country level) in parentheses. ${ }^{* * *} p<0.01,{ }^{*} p<0.05,{ }^{*} p<0.1$ 
Table 5. Mediation Analysis (Treatment $=$ electoral competition; Mediating variable $=$ RRA)

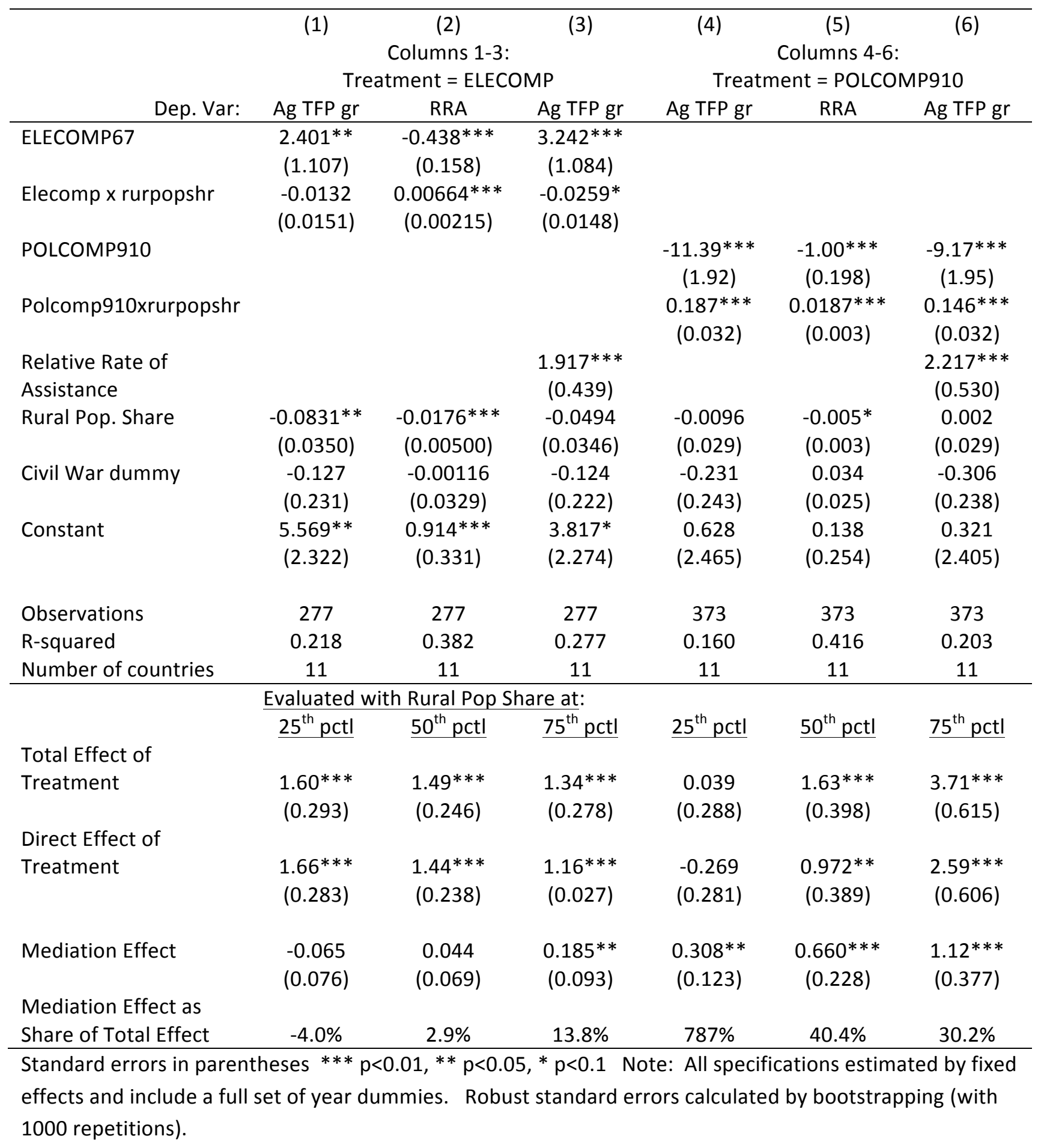

